\title{
IG ve DFIG'lerin Rüzgar Gücü Üretim Sistemleri İçin Karşılaştırılması
}

\author{
Mustafa Ergin ŞAHIN* ${ }^{*}$ a

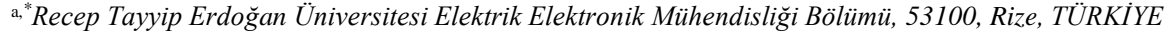

\begin{tabular}{|c|c|}
\hline MAKALE BİLGİSİ & ÖZ \\
\hline Alınma: 16.09.2020 & \multirow{8}{*}{$\begin{array}{l}\text { İndiksiyon ve iki beslemeli indiksiyon generatörleri rüzgar gücü sistemlerinde elektrik } \\
\text { üretimi için yaygın olarak kullanılır. İndiksiyon generatörlerin ve iki beslemeli indiksiyon } \\
\text { generatörlerin tanımları rüzgar enerji sistemleri için bu çalışmada verilmiştir. Farklı } \\
\text { bağlantı tipleri ve koşulları iki farklı rüzgar jeneratörü için şebeke ve rüzgar türbinleri için } \\
\text { bu çalışmada incelenmiştir. Bir rüzgar çiftliği modeli indiksiyon generatörü ve iki } \\
\text { beslemeli indiksiyon generatörü için MATLAB/Simulink de modellenmiştir. İlk olarak } \\
\text { simulasyon sonuçları normal çalışma koşulları için sunulmuş ve tartışlmıştır. İkinci } \\
\text { olarak ise rüzgar çiftliği modeli hata durumları için simule edilmiştir. Farklı hata koşulları } \\
\text { altındakı bu IG ve DFIG sonuçları statik kompanzatörün bir fonksiyonu olarak verilmiş }\end{array}$} \\
\hline Kabul: 06.12.2020 & \\
\hline Anahtar Kelimeler: & \\
\hline Rüzgar enerjisi, Üretim & \\
\hline sistemleri, İndiksiyon & \\
\hline generatörü, İki beslemeli & \\
\hline & \\
\hline & \\
\hline
\end{tabular}

mustafaerginsahin@yahoo https://dx.doi.org/10.30855/gmbd.2020.03.06

.com

\section{Comparison of IG and DFIG for Wind Power Generation Systems}

\section{ARTICLE INFO \\ Received: 16.09 .2020 Accepted: 06.12.2020 \\ Keywords: \\ Wind energy, Generation Systems, Induction Generator, Doubly Fed Induction Generator, STATCOM \\ "Corresponding Authors e-mail: mustafaerginsahin@yahoo com}

\begin{abstract}
Induction and doubly-fed induction generators are widely used in wind power systems for electricity generation. Description of induction generator (IG) and doubly-fed induction generator (DFIG) for wind power generation systems are given in this paper. Different connection types and conditions for two different types of wind generators with the grids and wind turbines are investigated in this study. A wind farm model is simulated using an induction generator and a doubly-fed induction generator in MATLAB/Simulink. The simulation results under normal operating conditions are presented and discussed firstly. Wind farm models are simulated under fault conditions secondly. The results of the IG and DFIG system under various fault conditions as a function of static compensator (STATCOM) are presented and discussed. The superiority and disadvantages of this system are given and evaluated.
\end{abstract}

https://dx.doi.org/10.30855/gmbd.2020.03.06

\section{INTRODUCTION (GIRIŞ̧)}

The unfulfilled energy demand and environmental problems caused by conventional fossil fuels have increased wind energy demand all around the world. Although considerable research has been employed to develop wind turbine technology, a lot of problems are not yet solved about wind energy and cannot become the first energy source in this area. One of these problems is connecting the wind turbine generators to the grid, and it causes power quality problems on the grid. The wind turbine generating voltage and power fluctuations are more than those produced by conventional generators $[1,2]$

Bu makaleye atıf yapmak için: M.E. Şahin, "Comparison of IG and DFIG for Wind Power Generation Systems," Gazi Journal of Engineering Sciences, vol. 6, no. 3, pp. 230-241, December, 2020, doi: https://dx.doi.org/10.30855/gmbd.2020.03.06. 
In wind energy systems are commonly used rotating electrical machines, and most of these machines are work as a motor or a generator. Mainly two types of generators are used in wind turbines. One of them is IG, and the other one is DFIG. The generator structures will be given more detail in the next section. Some different types of controllers are also, used to control this generator. These controllers are called pulsed controllers converters. The converter controllers are used for DFIG and energized the double windings $[3,4]$.

The wind power generation systems are investigated in different ways in the literature. IG and DFIG are investigated in different ways for some novel studies, control, and STATCOM applications. Also, some of them are a focus on reactive power measurement, tests, and energy storage applications $[5,6]$. This study mainly focuses on the comparison of MATLAB/Simulink models of different generator types [7]. It is possible to find some novel studies modeling and performance analyses of IG for wind turbines. However, they are not more advantageous than DFIG [8, 9, 10]. On the other side, describing DFIG details, and some novel studies are possible to find in the literature $[11,12]$. Some of these studies are related to the power of electronic parts and the converter control part. Also, some of them are related to modeling and dynamic stability analysis for variable speed wind energy generation [11-16]. These studies do not include any comparison of IG and DFIG works under normal operation conditions and fault conditions [17]. One of these studies has made a comparative study with STATCOM, but it is very restricted and does not include more detailed results [4]. Also, another study presents an innovative intelligent control system for the DFIG wind turbines to increase the performance of the wind turbine [18].

In this paper, the general information about induction generators and doubly-fed induction generators for wind power generation systems is given in the material and method section firstly. A $9 \mathrm{MW}$ power wind farm is simulated using an induction generator (IG) and a DFIG in MATLAB/Simulink. Secondly, wind farm models are simulated under fault conditions. The results of the IG and DFIG system under various fault conditions as a function of static compensator (STATCOM) are presented and discussed. The simulation results are evaluated by the way the superiority and disadvantages of this system.

\section{MATERIAL AND METHOD (MALZEME VE YÖNTEM)}

\subsection{Induction Generator (IG) and Wind Turbines (Indiksüyon jeneratörü ve Rüzgar Türbinleri)}

Electrical machines are used in wind energy systems commonly, and most of these can work as either a motor or a generator. There is also another more popular type of three-phase rotating machine, but as well as the synchronous generator. It can be used as a wind turbine generator and called an induction generator. The synchronous generator and the induction generator have similar fixed stator winding arrangement. Three-phase or single-phase voltage output produces a rotating magnetic field that is shown in Figure 1 [3].
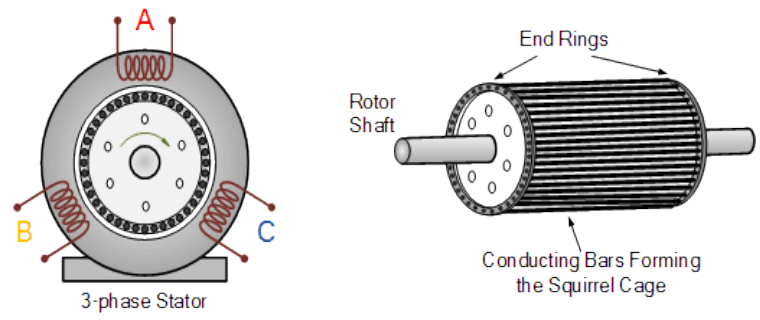

Figure 1. The cross-section and structure of the induction generator [3] (Indiksiyon jeneratörünün yapısı ve kesiti)

The difference between the stators rotating magnetic field and the rotor speed is called slip in an induction machine. In other words, the slip event is the difference in speed between the stators synchronous speed $\left(n_{s}=f / P\right)$ in rpm, and the rotors actual speed $n_{r}$ also in rpm, which is expressed as a percentage of slip. The slip $(s)$ is given in Equation 1.

$$
s=\frac{n_{s}-n_{r}}{n_{s}}
$$

An induction machine operating speed is always less than the rotational speed of the stator field that is called synchronous speed when works as a motor. An induction machine and its operating speed must be above the rated synchronous speed when it works as a generator as shown in Figure 2. At standstill slip is positive and equal to one $(\mathrm{s}=+1)$, the stators rotating magnetic field have the same rotational speed concerning both the stator and the rotor as the frequency of the rotor and stator currents is the same. The difference between the speed and frequency of the rotor and stator is zero at synchronous speed, so no electricity is consumed or produced, and slip is equal to zero $(s=0)$. As a result, the slip event becomes negative $(s=-1)$, and the induction machine generates a current. These situations are shown in Figure 2 torque/speed characteristics. 


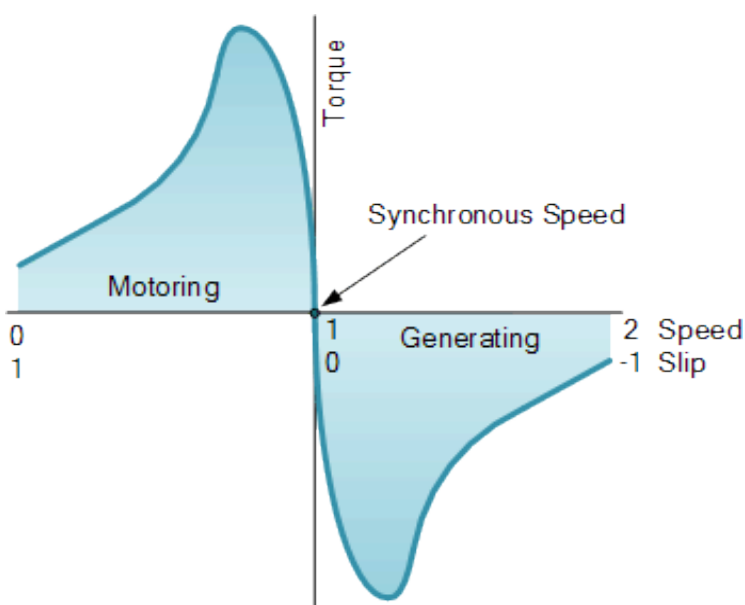

Figure 2. Torque/Speed characteristics of an induction machine (Indiksiyon makinasınin Tork/hı karakteristiği)

The speed of the induction generator will change with the wind energy rotational force applied to it, and continue to generate electricity until its rotational speed falls below idle. The generator increases or decreases its speed slightly if the torque changes depending on this useful mechanical property. So there will be less wear and tear on the gearbox resulting in low maintenance and long service life. That is the main reason for using an induction generator rather than a synchronous generator on a wind turbine when it is connected to the electrical grid directly.

The induction generator stator must be magnetized from the grid before it can generate electricity. Moreover, it can also run an induction generator by supplying the necessary magnetizing current from excitation capacitors connected across the stator terminals of the machine in an off-grid system. The circuit for a three-phase squirrel-cage induction machine at the off-grid system is shown in Figure 3 with the star connection excitation capacitors.

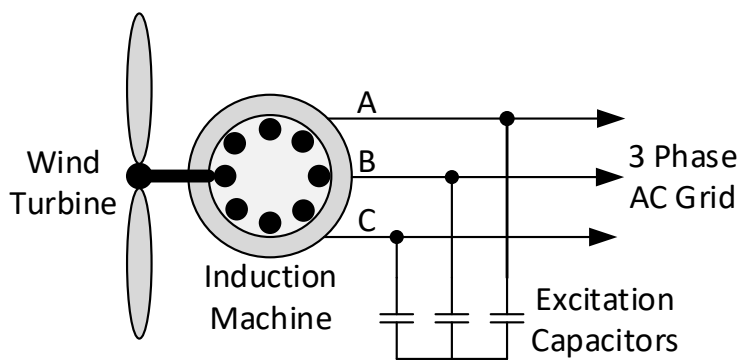

Figure 3. Three-phase squirrel-cage induction machine at the off-grid system (Şebekeden bağımsız üç fazlı sincap kafesli indüksiyon makinasi)

The excitation capacitors are used to provide the necessary reactive power for excitation otherwise be supplied by the grid. The induction generator is selfexcited only if the rotor has sufficient residual magnetism using these external capacitors. The generator output frequency and voltage are affected by the rotational speed, the turbine load, and the capacitance value in the self-excited mode.

The self-excited induction generator (SEIG) is a better solution in variable wind speed and remote areas, especially for wind-powered electric generation applications. They do not need an external power supply to produce the magnetic field. Two excitation capacitors connected across the three-phase windings and a three-phase induction generator can be converted into a variable speed single-phase induction generator. The capacitance value is $\mathrm{C}$ on one phase, and $2 \mathrm{C}$ across the other generator phase is shown in Figure 4.

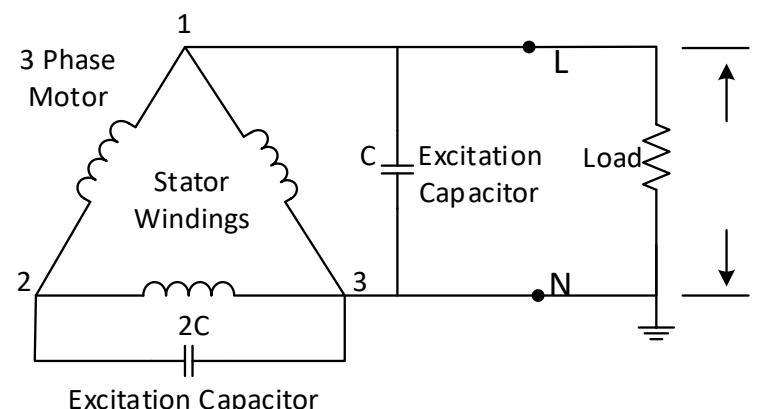

Figure 4. A three-phase IG converted into a singlephase IG (Ü̧̧ fazlı bir IG nin tek fazlı IG'ne dönüşümü)

\subsection{Doubly Fed Induction Generator (DFIG) and Wind Turbines (ikki Beslemeli İndiksiyon Jeneratörü (DFIG) ve Rüzgar Türbinleri)}

Doubly fed electrical generators have additional features that allow them to run at speeds slightly above or below their natural synchronous speed as to AC generators. It is useful for suddenly change wind speeds and high variable speed wind turbines. When wind hits a wind turbine suddenly, the blades try to speed up, but a synchronous generator is locked to the speed of the power grid and cannot speed up. High forces have occurred in the hub, gearbox, and generator as the power grid pushes back and causes wear and damage to the mechanism. Doubly fed generators are proposed as a solution to this solve this problem. The generated electricity comes out of windings fed with DC and an armature windings instead of the usual field, stationary and rotating windings both separately connected to equipment outside the generator that is shown in Figure 5. While one winding is directly connected to the output and produces three-phase AC power at the desired grid frequency, the other winding is connected to threephase AC power at a variable frequency. The input power is adjusted in frequency and phase to compensate for changes in the speed of the turbine. 
An AC to DC and DC to AC bidirectional converter is required for adjusting the frequency and phase.

DFIG is an electricity generating method which is widely used in wind turbines. It is based on a threephase wound rotor induction generator and a threephase slip ring assembly with brushes for access to the rotor windings. A better alternative is a brushless wound-rotor doubly-fed electric machine to avoid the multi-phase slip ring assembly. In the DFIG rotor windings are connected to the grid to controls both the rotor and the grid current via slip rings and back-toback voltage source converter (AC/DC/AC) that as shown in Figure 5 [7]. Thus, rotor frequency can freely differ from the grid frequency. It can be adjusted to the active and reactive power by using the converter to control the rotor currents fed to the grid from the stator independently of the generator's turning speed. Two-axis current vector control or direct torque control (DTC) is used as a control principle when high reactive currents are required from the generator [1].

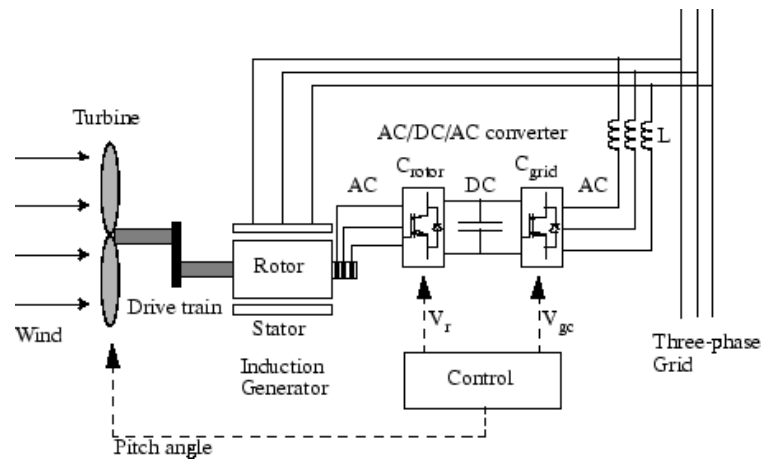

Figure 5. Doubly-fed induction generator with a wind turbine (Rüzgar türbini ve iki beslemeli indüksiyon jeneratör) [7]

Finally, a doubly-fed induction machine is a wound-rotor doubly-fed electric machine and has several advantages in wind power applications over a conventional induction machine. The induction generator can both import and export reactive power as the rotor circuit is controlled by a power electronics converter, which is a significant consequence for power system stability. The control of the rotor voltages and currents enables the induction machine to remain synchronized with the grid while the wind turbine speed changes. At last, the cost of the converter is low when compared with the other variable speed solutions.

The power is controlled by the tracking characteristic to follow a pre-defined power-speed characteristic figure. Such a characteristic by the ABCD curve superimposed to the mechanical power characteristics of the turbine obtained at different wind speeds is shown in Figure 6. The actual-speed of the turbine $\omega_{r}$ is measured, and the related mechanical power of the tracking characteristic is used as the reference power for the power control loop. The tracking characteristic is defined by four points $\mathrm{A}, \mathrm{B}$, $\mathrm{C}$, and $\mathrm{D}$. Between point $\mathrm{B}$ and point $\mathrm{C}$, the tracking characteristic is the place of the maximum power of the turbine [7].

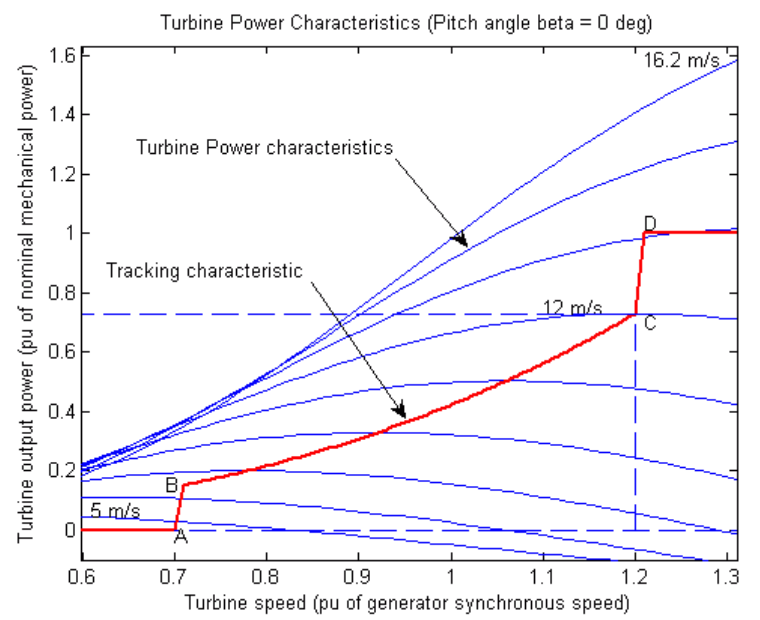

Figure 6. Turbine characteristics and tracking characteristic [7] (Türbin ve takip karakteristikleri)

\section{SIMULATION RESULTS (BENZETIM SONUÇLARI)}

The simulation models and simulation results of IG and DFIG in MATLAB/Simulink are given in this section. The simulation results are obtained for various fault conditions and compared with normal operating conditions.

\subsection{IG Used Wind Farm Simulation and Results for Normal Operation (Rüzgar Çiftliği simulasyonunda kullanılan IG ve Normal Çalışma Sonuçları)}

Investigated an example simulation model of a 9 MW wind farm using IG driven by variable-pitch wind turbines in MATLAB/Simulink is shown in Figure 7. The wind farm model consisting of six 1.5 MW wind turbines is connected to a $25 \mathrm{kV}$ distribution system that exports power to a $120 \mathrm{kV}$ grid through a $25 \mathrm{~km} 25 \mathrm{kV}$ feeder. Squirrel-cage induction generators (IG) are used in wind turbines rotor that is driven by a variable-pitch wind turbine. The stator winding is connected directly to the $60 \mathrm{~Hz}$ grid, and the pitch angle is controlled to limit the generator output power at its nominal value for winds exceeding the $9 \mathrm{~m} / \mathrm{s}$ nominal speed. The IG speed must be slightly above the synchronous speed to generate power. The IG speed varies approximately between $1 \mathrm{pu}$ at no load and $1.005 \mathrm{pu}$ at full load. 


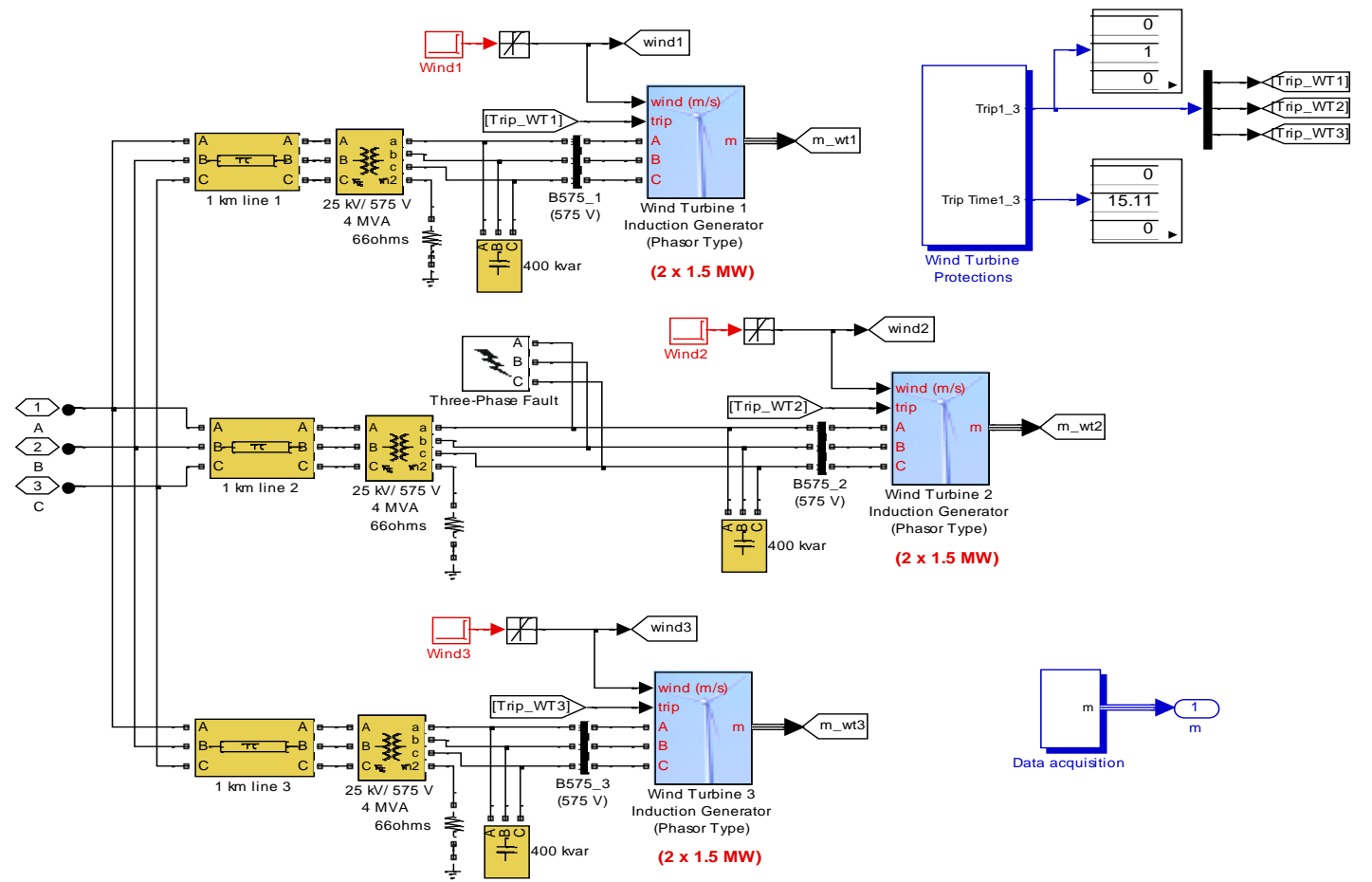

Figure 7. $9 \mathrm{MW}$ wind farm MATLAB/Simulink model using IG [8] (IG kullanılan 9 MW rüzgar çiftliği MATLAB/Simulink modeli)

The simulation results for IG used $9 \mathrm{MW}$ wind farm for normal operating conditions are given in Figure 8. Generated voltage and reactive power as a $p u$ for $6 \mathrm{~m} / \mathrm{s}$ wind speed are given in Figure 8 (a) for pitch angle $0^{\circ}$, and Figure 8 (b) for pitch angle $45^{\circ}$. Generated voltage and reactive power as a $p u$ for $9 \mathrm{~m} / \mathrm{s}$ wind speed are given in Figure 8 (c) for pitch angle $0^{\circ}$, and Figure 8 (d) for pitch angle $45^{\circ}$. Generated voltage and reactive power as a $p u$ for $9 \mathrm{~m} / \mathrm{s}$ wind speed are given in Figure 8 (e) for pitch angle $0^{\circ}$, and Figure 8 (f) for pitch angle $45^{\circ}$.

The simulation results show that for low wind speeds applications depends on the pitch angle, some deformations are acquired on the generated voltage and generated reactive power. Above the critical speed values, the generated voltage and reactive power do not change depending on the pitch angle. It can be said that the pitch angle in the variable speeds tries to stabilize the wind speed, but it does not fully work truly in every condition. So the IG is not the best solution for variable speed under the nominal speeds.
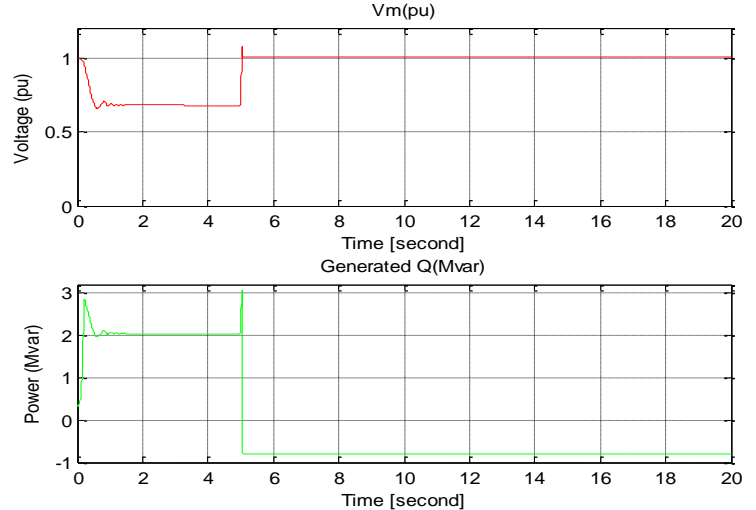

(a)
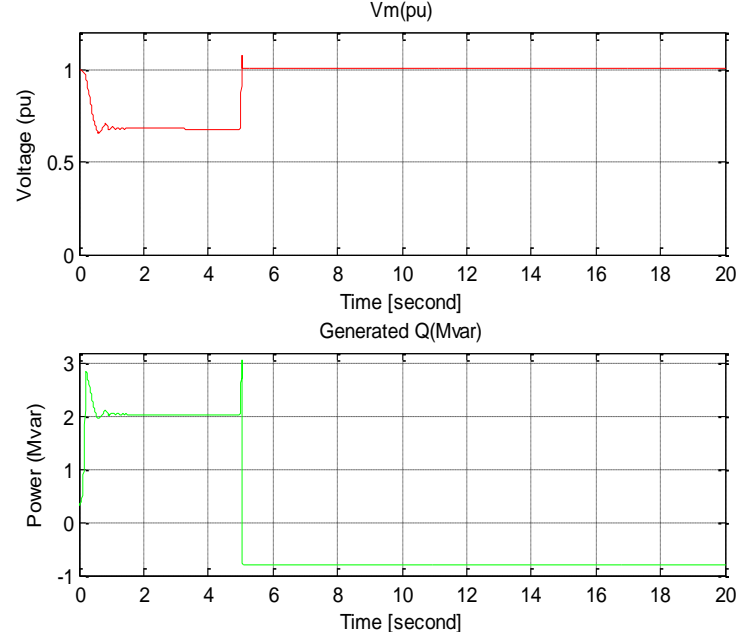

(b) 


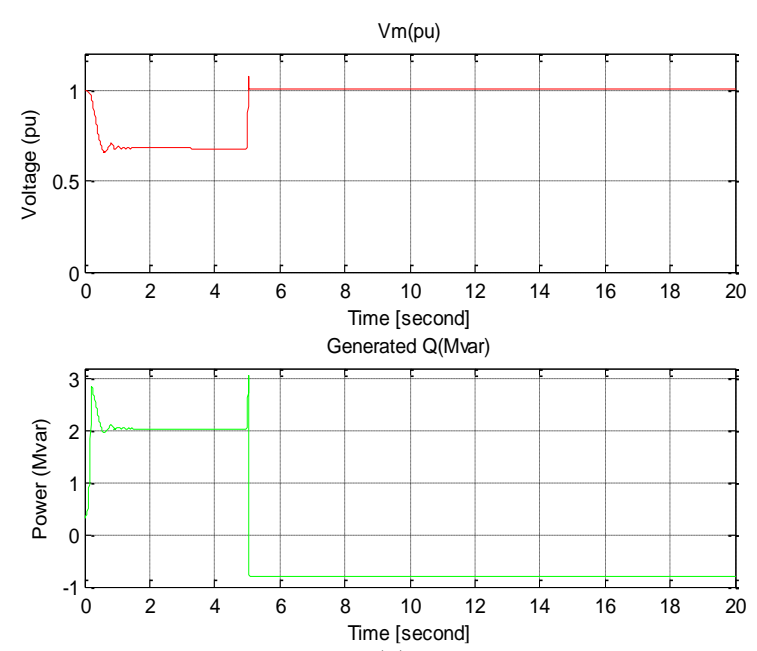

(c)
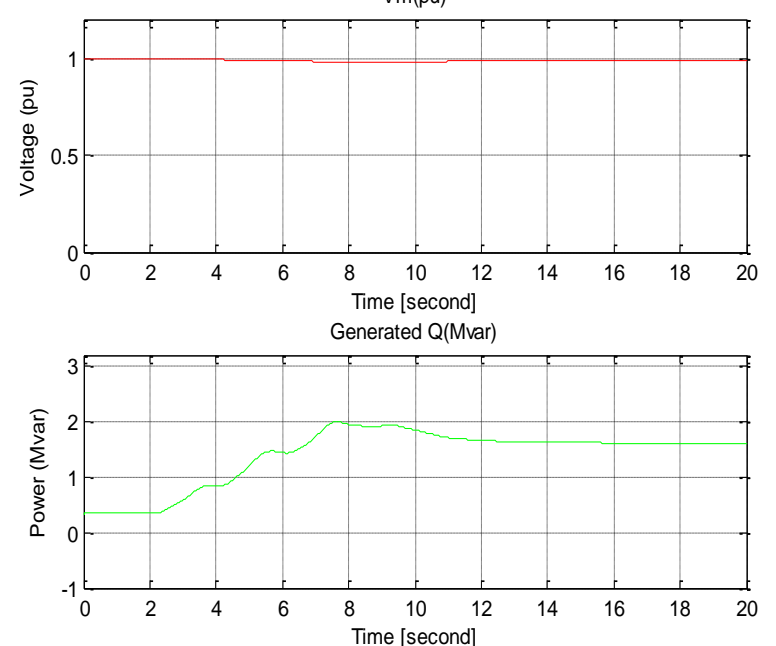

(d)
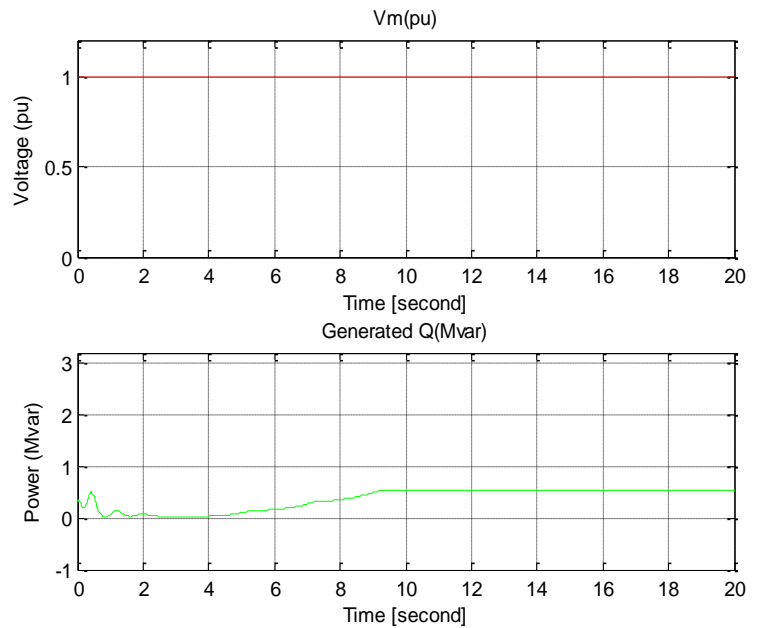

(e)
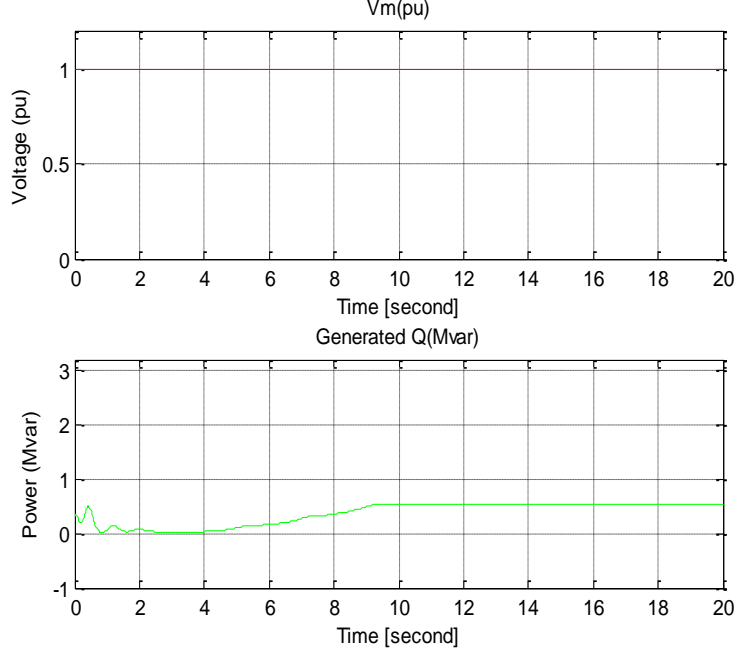

(f)

Figure 8 . Generated voltage and reactive power as a pu; for $6 \mathrm{~m} / \mathrm{s}$ wind speed a) Pitch angle $0^{\circ}$, b) Pitch angle $45^{\circ}$; for $9 \mathrm{~m} / \mathrm{s}$ wind speed, c) Pitch angle $0^{\circ}$, d) Pitch angle $45^{\circ}$; for $12 \mathrm{~m} / \mathrm{s}$ wind speed, e) Pitch angle $0^{\circ}$, f) Pitch angle $45^{\circ}$ (pu olarak üretilen gerilim ve reaktif güç; $6 \mathrm{~m} / \mathrm{s}$ rüzgar hızı için, a) Kanat açısı $0^{\circ}$, b) Kanat açısı $45^{\circ}$; $9 \mathrm{~m} / \mathrm{s}$ rüzgar hızı için, c) Kanat

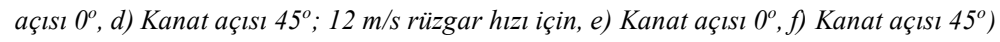

\subsection{DFIG Used Wind Farm Simulation and Results for Normal Operation (Normal koşullarda kullanilan DFIG kullanılan rüzgar çiftliği simulasyonu ve sonuçlart)}

The simulation model of a $9 \mathrm{MW}$ wind farm using DFIG driven by wind turbines is investigated in MATLAB/Simulink is shown in Figure 9. A 9 MW wind farm model consisting of six 1.5 MW wind turbines connected to a $25 \mathrm{kV}$ distribution system exports power to a $120 \mathrm{kV}$ grid through a 30 meter, $25 \mathrm{kV}$ feeder. The DFIG used wind turbines consist of a wound rotor induction generator and an AC/DC/AC IGBT-based PWM converter. The DFIG technology allows extracting maximum energy from the wind for low wind speeds by optimizing the turbine speed while minimizing mechanical stresses on the turbine. The wind speed is maintained at $15 \mathrm{~m} / \mathrm{s}$ in this model, and the control system uses a torque controller to maintain the wind speed at $1.2 \mathrm{pu}$. The reactive power generated by the wind turbine is adjusted at 0 Mvar.

The simulation results for DFIG used $9 \mathrm{MW}$ wind farm for normal operation mode are given in Figure 10. Generated voltage and reactive power as a pu for $6 \mathrm{~m} / \mathrm{s}$ wind speed are given in Figure 10 (a) for pitch angle $0^{\circ}$, and Figure 10 (b) for pitch angle $45^{\circ}$. Generated voltage and reactive power as a pu for 9 $\mathrm{m} / \mathrm{s}$ wind speed are given in Figure 10 (c) for pitch angle $0^{\circ}$, and Figure 10 (d) for pitch angle $45^{\circ}$. Generated voltage and reactive power as a pu for 15 $\mathrm{m} / \mathrm{s}$ wind speed are given in Figure 10 (e) for pitch angle $0^{\circ}$, and Figure 10 (f) for pitch angle $45^{\circ}$. 


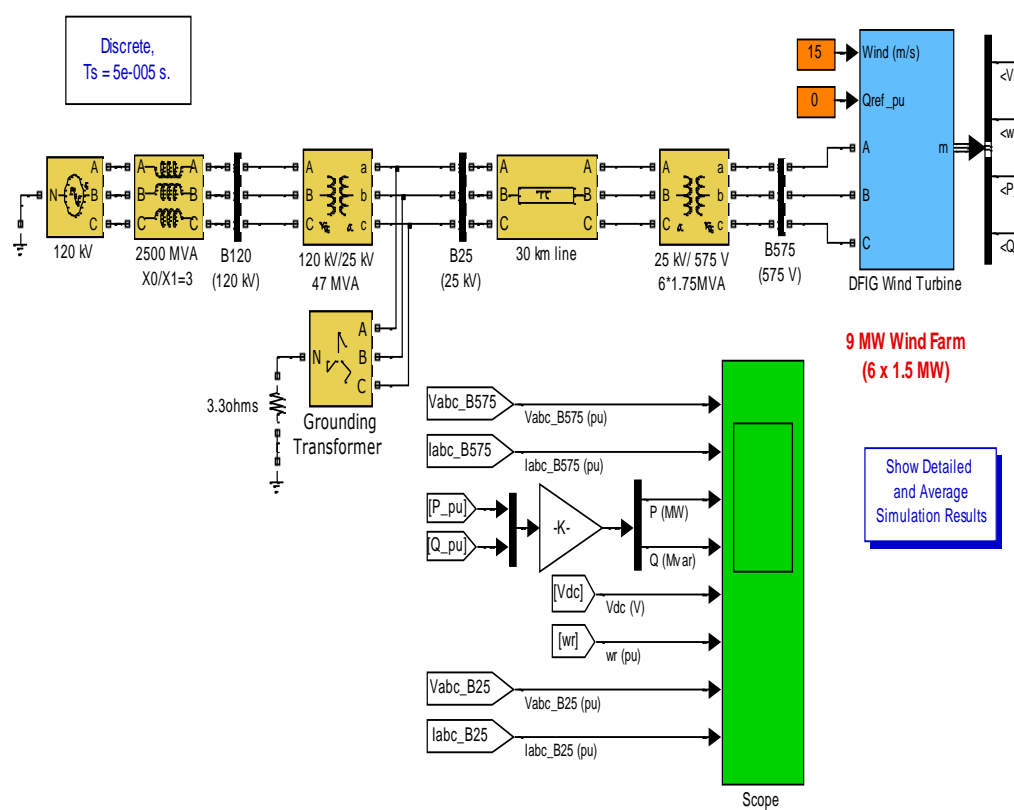

Figure 9. 9 MW wind farm MATLAB/Simulink model of DFIG [6] (9MW DFIG rüzgar çiftliği MATLAB/Simulink modeli)
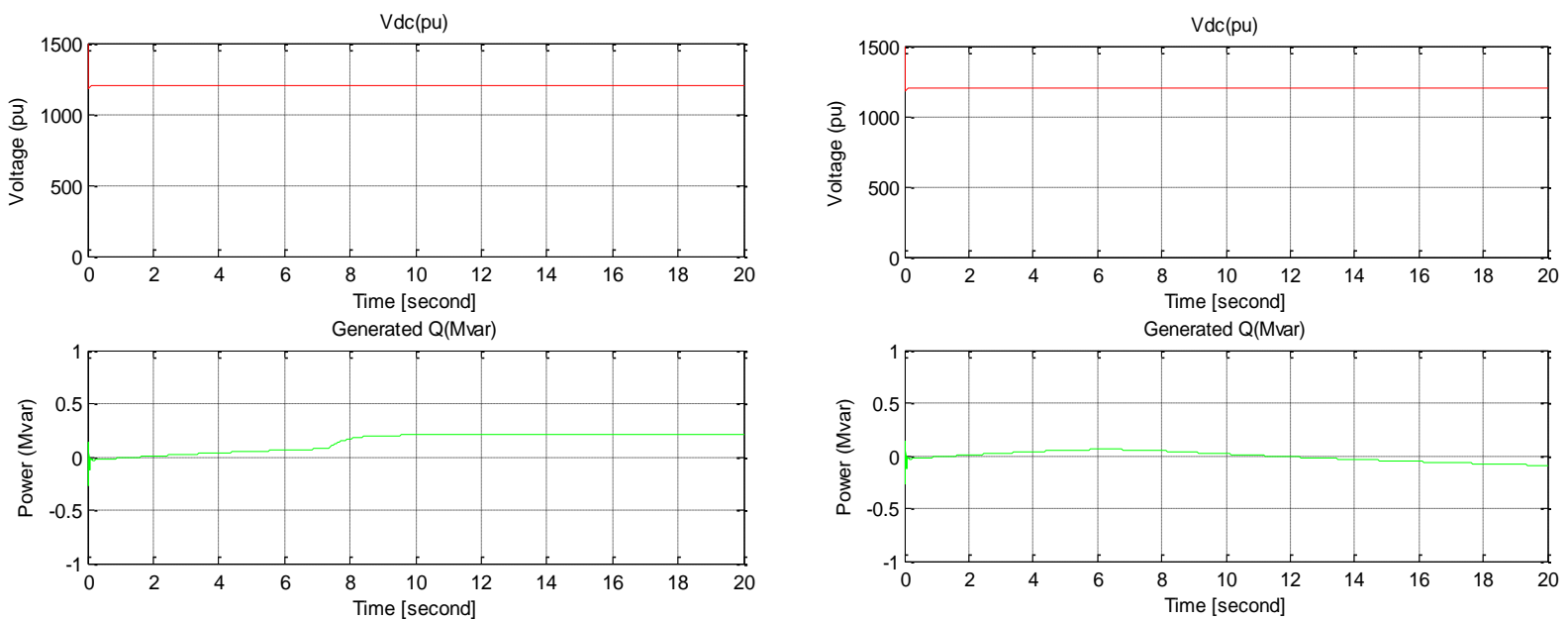

(a)
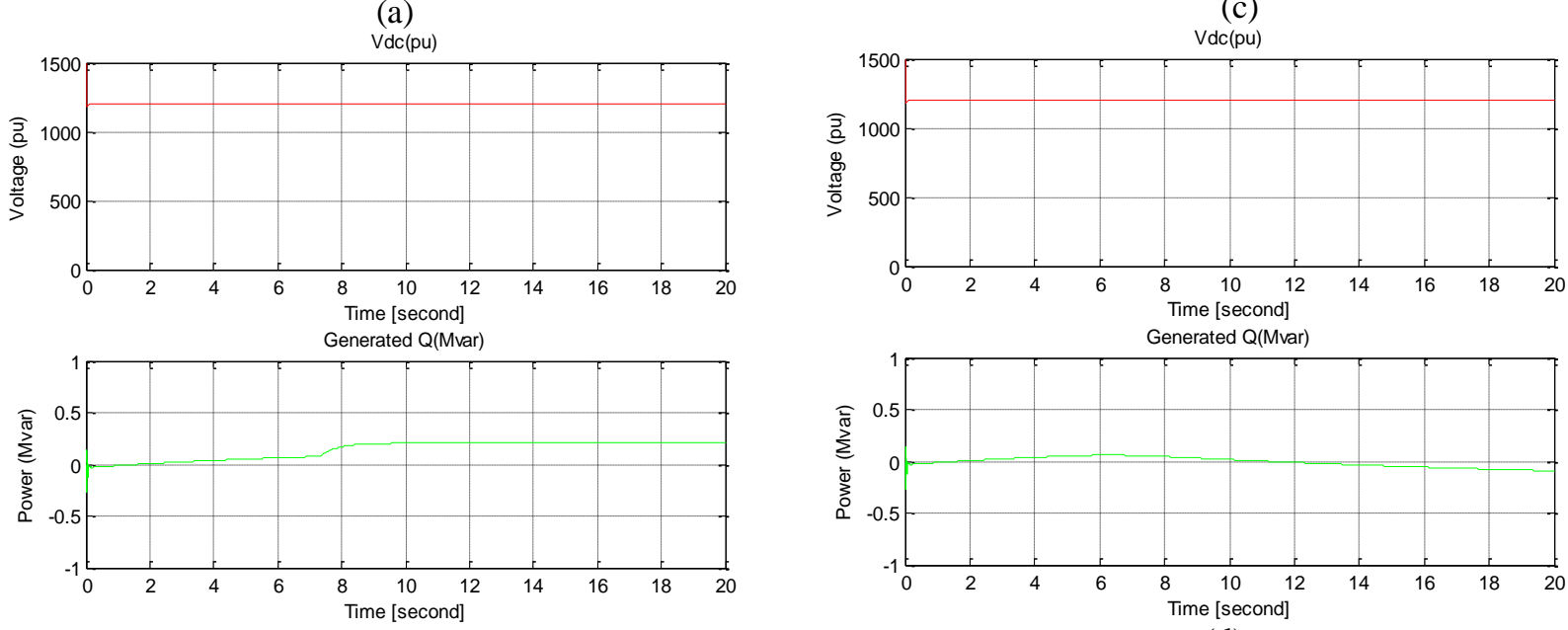

(b)

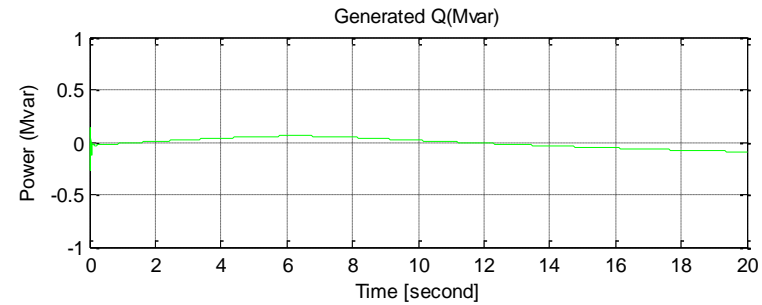

(d) 

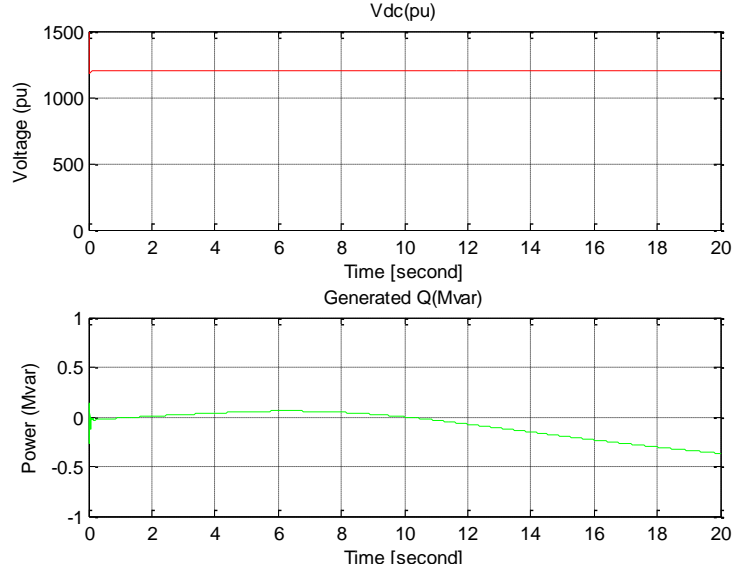

(e)
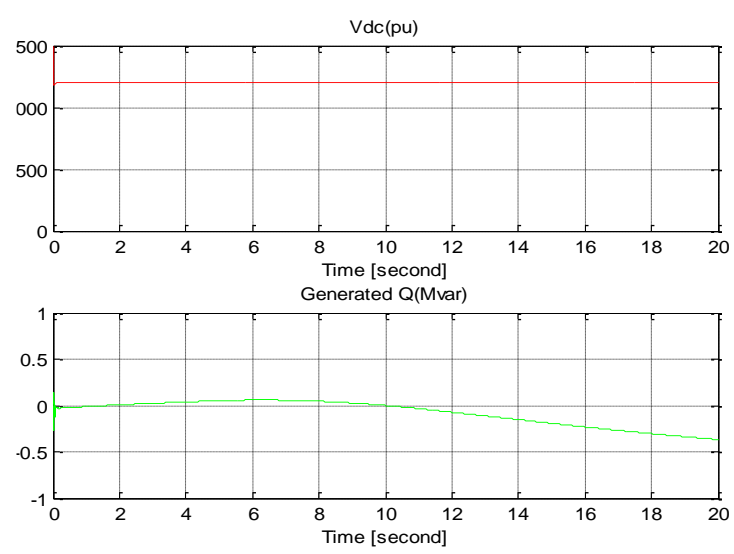

(f)

Figure 10. Simulation results for $6 \mathrm{~m} / \mathrm{s}$ wind speed; a) Pitch angle $0^{\circ}$, b) Pitch angle $45^{\circ}$, for $9 \mathrm{~m} / \mathrm{s}$ wind speed c) Pitch angle $0^{\circ}, \mathrm{d}$ ) Pitch angle $45^{\circ}$, for $12 \mathrm{~m} / \mathrm{s}$ wind speed e) Pitch angle $0^{\circ}$, f) Pitch angle $45^{\circ}$ (Simulasyon sonuçlarl; 6 $\mathrm{m} / \mathrm{s}$ rüzgar hızı için, a) Kanat açısı $0^{\circ}$, b) Kanat açısı $45^{\circ} ; 9 \mathrm{~m} / \mathrm{s}$ rüzgar hızı için, c) Kanat açısı $0^{\circ}$, d) Kanat açısı $45^{\circ} ; 12 \mathrm{~m} / \mathrm{s}$ rüzgar hızı için, e) Kanat açısı $0^{\circ}$, f) Kanat açısı $45^{\circ}$ )

The simulation results show that for low wind speeds applications depends on the pitch angle, not a lot of deformations are acquired on the generated voltage generated reactive power. Also, above the critical speed values, the generated voltage and reactive power do not change depending on the pitch angle. It can be said that the pitch angle in the variable speeds tries to stabilize the wind speed and works more truly than IG in every condition. So the DFIG is a better solution for variable wind speeds under the nominal wind speeds.

\subsection{IG Used Wind Farm Simulation Results under Various Fault Conditions (Rüzgar çiftliğinde kullanılan IG için farklı hata koşullarında simulasyon sonuçları)}

Simulation results under short-circuit fault conditions between any phase and the ground for the induction generator and wind turbine system as a function of STATCOM are given in Figure 11. Different faults for different phases are tried, and the results are shown. The results are obtained for $9 \mathrm{~m} / \mathrm{s}$ wind speed ad $0^{\circ}$ pitch angle.
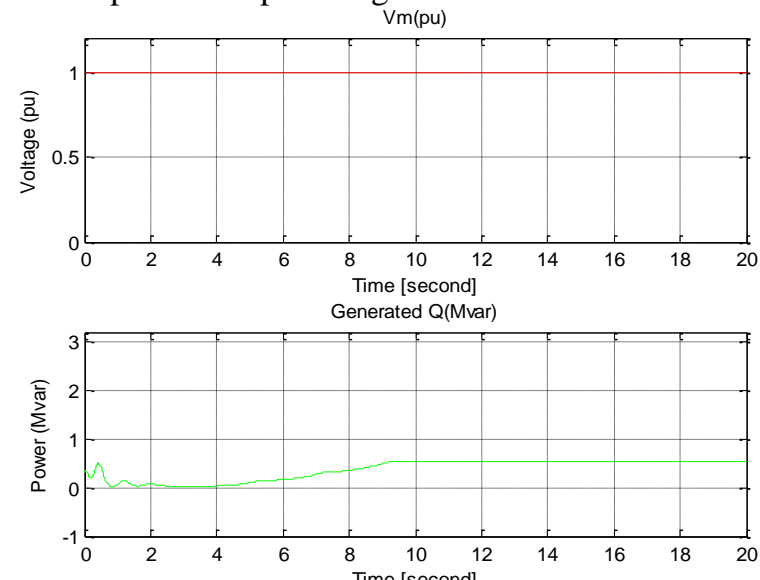

(a)
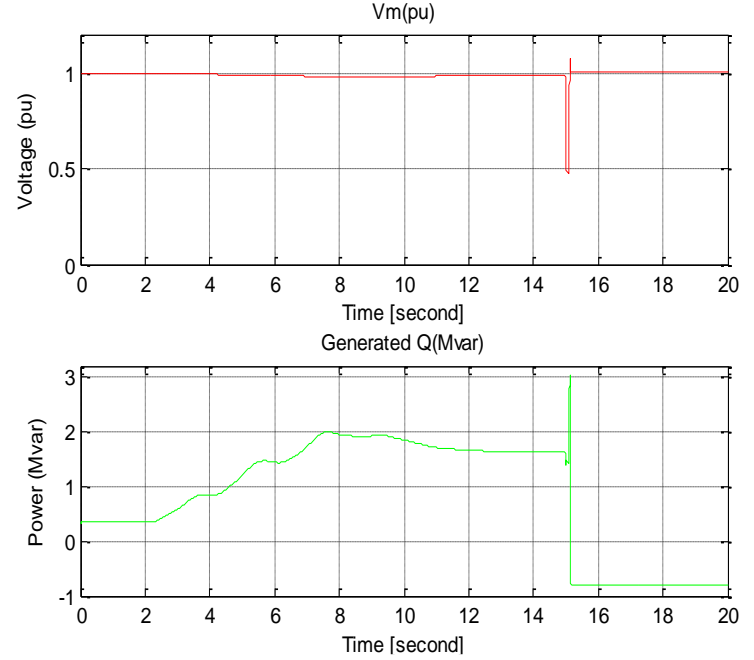

(b)
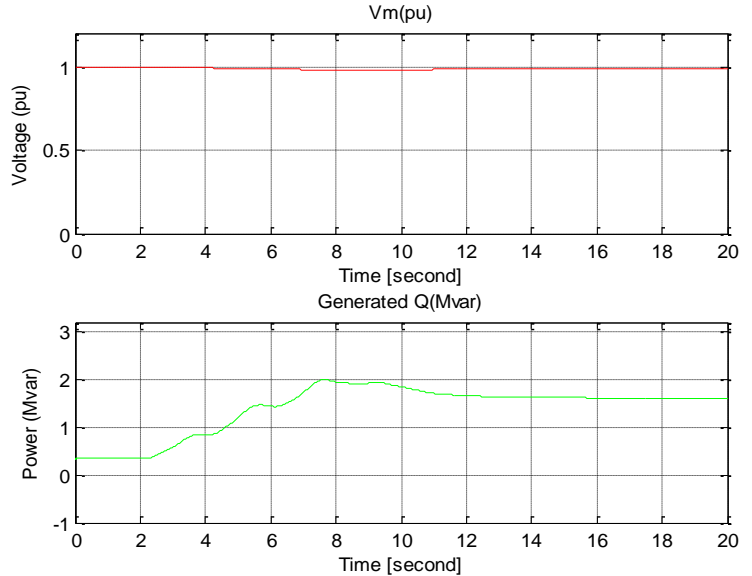

(c) 

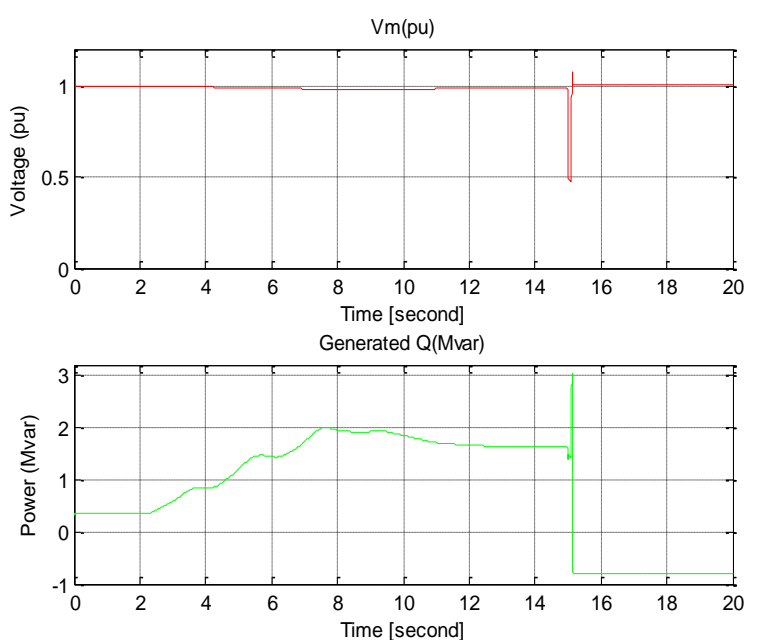

(d)

Figure 11. Measured voltage (up), generated reactive power (down) under short circuit fault results between any phase and the ground, a) fault in phase A and B, b) fault in phase $B, c$ ) fault in phase $C, d$ ) fault in $A$, $\mathrm{B}, \mathrm{C}$ phase. (Ölçülen gerilim (üstte) üretilen reaktif güç (altta) herhangi bir faz ile toprak arasinda kisa devre hata koşulları altinda, a) $A$ ve $B$ fazlar arasinda hata, b) B fazinda hata, c) $C$ fazinda hata, d) $A, B, C$ fazlarinda hata)

The simulation results show that if the short circuit fault occurred in two-phase voltage drops, reactive power catches up with the previous results before the error. If the fault occurs in one phase to ground, the voltage drops a little, and the reactive power increases small previous results before the error, but the short circuit fault is not shown on STATCOM directly. If the fault occurs in three phases, the short circuit fault is shown on STATCOM temporarily, and the voltage value catches the previous voltage. Also, the reactive power drops the negative values.

\subsection{DFIG Used Wind Farm Simulation Results under Various Fault Conditions (Rüzgar çiftliğinde kullanılan DFIG için farklı hata koşullarında simülasyon sonuçlari)}

Simulation results under short-circuit fault conditions between any phase and the ground for doubly-fed induction generator and wind turbine systems are given in Figure 12. Different faults for different phases are tried, and the results are shown for the wind turbine.
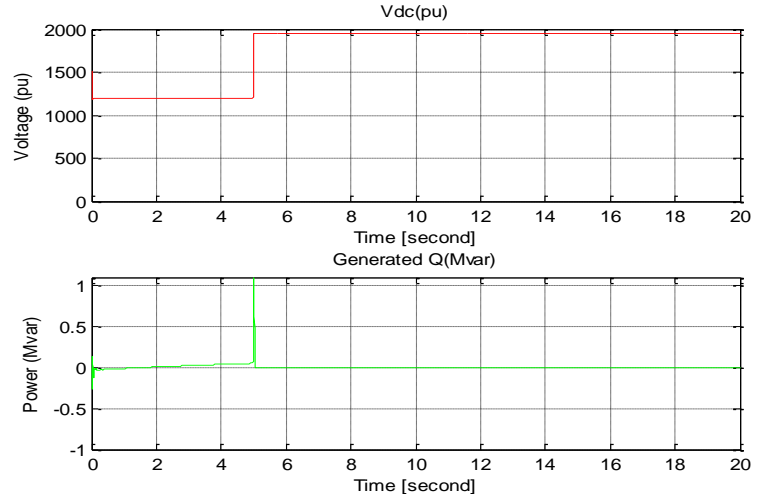

(a)
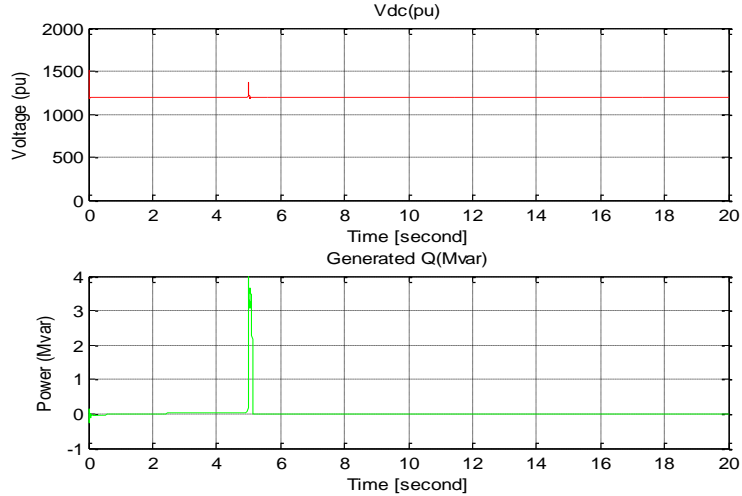

(b)
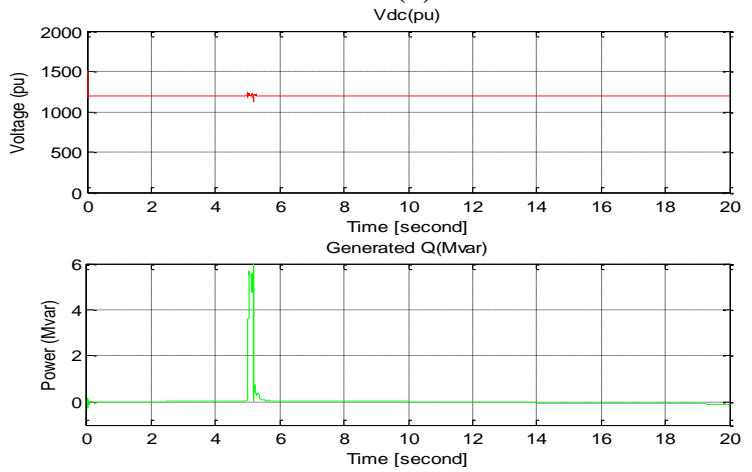

(c)
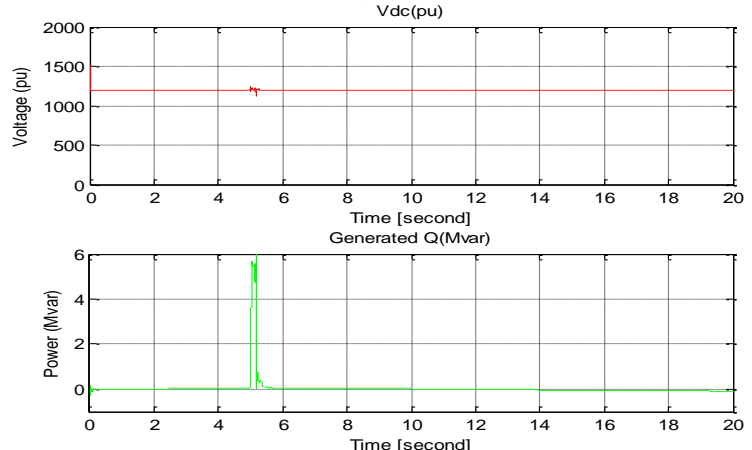

(d)

Figure 12. Short circuit fault results between any phase and the ground, a) fault in Phase A, B, C wind turbine $\mathrm{b}$ ) fault in phase $\mathrm{A}, \mathrm{B}$ wind turbine c) Fault in phase $\mathrm{A}$ wind turbine, d) Fault in phase $\mathrm{C}$ wind turbine (Herhangi bir faz ile toprak arasında kisa devre hatası sonuçlarl, a) Rüzgar türbinin $A, B, C$ fazlarinda hata, b) A, B fazlarında c) $A$ fazında, d) C fazinda hata) 
The simulation results show that if the short circuit fault occurs in one, two, or three phases the simulation results are well because after the fault the simulation results catch up with the previous voltages, power, and speed in every condition. This shows that the DFIG supply better controls the IG in fault conditions. Also, it is better to protect the wind turbines against faults and forced conditions.

The summary of the simulation results is shown in Table 1 and 2. Comparison of IG and DFIG voltage and power variation for different wind speeds and pitch angle under normal conditions are shown in
Table 1. Comparison of IG and DFIG voltage and power variation for $9 \mathrm{~m} / \mathrm{s}$ wind speed and $0^{\circ}$ pitch angle under fault conditions are shown in Table 2. The simulation results of DFIG show batter results for normal and fault conditions. For DFIG, voltage is more stable, and reactive power has not been affected by the variation of wind speeds and pitch angle for high wind speeds. Although the fault conditions in phases affect the voltage stabilization and generated power for IG, the fault conditions in phases do not affect the voltage stabilization and generated power for DFIG.

Table 1. Comparison of IG and DFIG voltage and power variation for different wind speed and pitch angle under normal conditions (Farklı rüzgar hızları ve kanat açıları için normal koşullar altında IG ve DFIG'ün gerilim ve güç değişimleri)

\begin{tabular}{|c|c|c|c|c|c|}
\hline \multirow{2}{*}{$\begin{array}{c}\text { Wind } \\
\text { speed }\end{array}$} & Type & \multicolumn{2}{|c|}{ IG } & \multicolumn{2}{c|}{ DFIG } \\
\cline { 2 - 6 } & Pitch angle & Voltage & Power & Voltage & Power \\
\hline \multirow{2}{*}{$6 \mathrm{~m} / \mathrm{s}$} & $0^{\circ}$ & Effected & Effected & Stable & Effected \\
\cline { 2 - 6 } & $45^{\circ}$ & Effected & Effected & Stable & Effected \\
\hline \multirow{2}{*}{$9 \mathrm{~m} / \mathrm{s}$} & $0^{\circ}$ & Effected & Effected & Stable & Not effected \\
\cline { 2 - 6 } & $45^{\circ}$ & Stable & Not effect & Stable & Not effected \\
\hline \multirow{2}{*}{$12 \mathrm{~m} / \mathrm{s}$} & $0^{\circ}$ & Stable & Not effect & Stable & Not effected \\
\cline { 2 - 6 } & $45^{\circ}$ & Stable & Not effect & Stable & Not effected \\
\hline
\end{tabular}

Table 2. Comparison of IG and DFIG voltage and power variation for $9 \mathrm{~m} / \mathrm{s}$ wind speed ad $0^{\circ}$ pitch angle under fault conditions (9 m/s rüzgar hızı ve $0^{\circ}$ kanat açısı için hata koşulları altında IG ve DFIG'ün gerilim ve güç değiş̧imleri)

\begin{tabular}{|c|c|c|c|c|}
\hline Type & \multicolumn{2}{|c|}{ IG } & \multicolumn{2}{c|}{ DFIG } \\
\hline Fault in phase & Voltage & Power & Voltage & Power \\
\hline A, B & Stable & Not effected & Stable & Not effected \\
\hline B & Effected & Effected & - & - \\
\hline C & Not stable & Not effected & Stable & Not effected \\
\hline A, B, C & Effected & Effected & Not stable & Not effected \\
\hline A & - & - & Stable & Not effected \\
\hline
\end{tabular}

\section{CONCLUSION (SONUÇ ve ÖNERILER)}

In this paper, a description of IG and DFIG for wind power generation systems is given. The advantages and disadvantages of this type of generators are investigated in a comparable form. The simulation setup is described for IG and DFIG. The simulation results under normal operation situation for IG and DFIG are presented and discussed. Also, the simulation results under various fault conditions for the IG system are presented and discussed. The results of the DFIG system under fault conditions are presented and discussed. The DFIG simulation results are seen well than the IG system, especially in fault conditions. This result are compared in a comperation table. It can be said that using DFIG can be preferred in a wind energy conversion system due to its advantages. This simulation model can be implemented experimentally to test realization and reliability.

\section{ACKNOWLEDGMENTS (BİLGILENDIRME)}

This study was expanded from a course study at Aalborg University during the postdoctoral research and presented firstly in an ICADET 2019 conference (Bayburt-Turkey). The author wishes to thank TUBITAK, 2219 postdoctoral research program with a 1059B191700997 application number.

\section{CONFLICT OF INTEREST STATEMENT (ÇIKAR ÇATIŞMASI BILDIIRIMI)}

The authors reported no potential conflict of interest.

\section{REFERENCES (KAYNAKLAR)}

[1] S. Müller, M. Diecke, R. W. De Doncker, "Doubly Fed Induction Generator Systems for Wind Turbines," IEEE Industry Applications Magazine, vol. 8, no. 3, pp. 27-33, 2002. doi: 10.1109/2943.999610 
[2] F. Zhang, S.Yu, H. Wang, Y. Wang, D. Wang, "Overview of research and development status of the brushless doubly-fed machine system," Chinese Journal of Electrical Engineering, vol. 2, no. 2, pp. 113, 2016. doi: 10.23919/CJEE.2016.7933122

[3] Induction Generator, "Alternative Energy Tutorials". [Online]. Available: http://www.alternative-energy-tutorials.com/windenergy/induction-generator.html, [Accesed: 1-March2019].

[4] V. Patel, A. Kashiv, K. Aslam, H. K. Verma, "Comparative Analysis between IG and DFIG for Wind Energy Conversion Systems using STATCOM," International Journal of Energy and Power Engineering. Special Issue: Distributed Energy Generation and Smart Grid, vol. 3, no. (6-2), pp. 21-26, $2014 . \quad$ doi: 10.11648/j.ijepe.s.2014030602.14

[5] J. Niiranen, "About the active and reactive power measurements in unsymmetrical voltage dip ridethrough testing," Wind Energy, vol.11, pp. 121-131, 2008. doi: https://doi.org/10.1002/we.254

[6] P. C. Kjaer, R. Lærke, G. C. Tarnowski, "Ancillary services provided from wind power plant augmented with energy storage,"15th European Conference on Power Electronics and Applications (EPE), pp. 1-7, 2013. doi: 10.1109/EPE.2013.6634654

[7] Wind Turbine Doubly-Fed Induction Generator, "Technical Support". [Online]. Available: https://www.mathworks.com. [1 March 2019].

[8] M. E. Şahin, A. M. Sharaf, H. İ. Okumuş, "A novel filter compensation scheme for single phaseself-excited induction generator micro wind generation system," Scientific Research and Essays, vol. 7, no. 34, pp. 3058-72, 2012. doi: https://doi.org/10.5897/SRE11.708

[9] A. Garg, R. P. Singh, "Dynamic Performance Analysis of IG based Wind Farm with STATCOM and SVC in MATLAB/Simulink," International Journal of Computer Applications, vol.71, no. 23, 2013.

[10] S. M. Bolik, "Modelling and Analysis of Variable Speed Wind Turbines with Induction Generator during Grid Fault," Ph.D. Dissertation, Aalborg Universitet, Institut for Energiteknik, 2004.

[11] S. O. Madbouly, A. M. Sharaf, "A Novel Regulation Inter-Coupled Control Scheme for Doubly Fed Wind Induction System," Turkish Journal of
Electromechanics \& Energy, vol. 1, no. 2, pp. 8-16, 2016. doi: https://sloi.org/urn:sl:tjoee126

[12] S. Courseware, "Principles of Doubly-Fed Induction Generators," Technical documents, Festo Didactic Ltee/Ltd, Canada, 2011.

[13] R. Pena, J. C. Clare, G. M. Asher, "Doubly fed induction generator using back-to-back PWM converters and its application to variable-speed windenergy generation," IEEE Proc.-Electr. Power Appl., vol. 143, no. 3, pp. 231-241, 1996. doi: 10.1049/ipepa: 19960288

[14] V. Akhmatov, "Variable-Speed Wind Turbines with Doubly-Fed Induction Generators, Part I: Modelling in Dynamic Simulation Tools," Wind Engineering, vol. 26, no. 2, pp. 85-108, 2002. doi: https://doi.org/10.1260/030952402761699278

[15] N. W. Miller, J. J. Sanchez-Gasca, W. W. Price, R. W. Delmerico, "Dynamic Modeling of GE 1.5 and 3.6 MW Wind Turbine-Generators for Stability Simulations," GE Power Systems Energy Consulting, IEEE WTG Modeling Panel, Session, July 2003.

[16] M. Leila, M. Mounira, O. Amel, S. Salah, "Modelling and control of wind turbine doubly-fed induction generator with MATLAB Simulink", Global Journal of Computer Sciences: Theory and Research, vol. 7, no. 2, pp. 77-91, 2017.

[17] M. E. Şahin, "Comparison of IG and DFIG for Wind Power Generation Systems," 3rd International Conference on Advanced Engineering Technologies (ICADET 2019), Bayburt, Turkey, 2019.

[18] M. Abouheaf, W. Gueaieb, and A. Sharaf, "Model-free adaptive learning control scheme for wind turbines with doubly fed induction generators," IET Renewable Power Generation, vol. 12, no. 14, pp. 1675-1686, 2018. doi: 10.1049/iet-rpg.2018.5353

\section{Mustafa Ergin ŞAHİN}

Mustafa Ergin Şahin was born in, 1978 in Trabzon, Turkey. He received his B.Sc. degree in Electrical \& Electronics Engineering from Karadeniz Technical University (KTU), M.Sc. degree from Gazi University in Ankara, and a Ph.D. degree from KTU, Trabzon, Turkey, in 2002 and 2006, 2014, respectively. He was a Guest Researcher with the TUBITAK 2219 postdoctoral research program at the Department of Energy Technology, Aalborg University from September 2018 to September 2019. He is currently an assistant professor in the Electrical and Electronics Engineering Department at RTE University. He was worked on different projects on low voltage power 
systems and relay manufacturers for power systems. $\mathrm{He}$ is an active reviewer for scientific journals in the field. He is also a member of the Chamber of Electrical Engineers in Turkey. His main research interests are power electronics and the utilization of renewable energy. He is the author of two books in circuit analysis and measurement, electronics laboratory. 